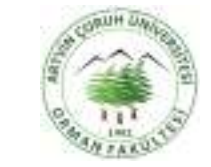

\title{
Burdur kenti açık-yeşil alan potansiyelinin belirlenmesi
}

\section{Identification of open-green lands' potential in Burdur city, Turkey}

\author{
Altunay ULU AKŞiT ${ }^{1}$ Cengiz YÜCEDAĞ ${ }^{-}$Latif Gürkan KAYA ${ }^{2}$ Hüseyin Samet AŞIKKUTLU ${ }^{2}$ \\ ${ }^{1}$ Burdur Mehmet Akif Ersoy Üniversitesi, Fen Bilimleri Enstitüsü, Burdur \\ ${ }^{2}$ Burdur Mehmet Akif Ersoy Üniversitesi, Mühendislik Mimarlık Fakültesi, Peyzaj Mimarlığı Bölümü, Burdur
}

\section{Eser Bilgisi / Article Info}

Araştırma makalesi / Research article DOI: 10.17474/artvinofd.732808

Sorumlu yazar / Corresponding author Cengiz YÜCEDAĞ

e-mail: cyucedag@mehmetakif.edu.tr

Geliş tarihi / Received

05.05.2020

Düzeltme tarihi / Received in revised form

26.06.2020

Kabul Tarihi / Accepted

30.06.2020

Elektronik erişim / Online available 15.09.2020

\section{Anahtar kelimeler:}

Açık-Yeşil Alan

Burdur

Nicelik

Nitelik

Standart

\section{Keywords:}

Open-Green Land

Burdur

Quantity

Quality

Standard

\begin{abstract}
Özet
Bu çalışmanın amacı, Burdur kenti açık-yeşil alanlarının mevcut durumunu incelemek, yeterlilikleri ve işlevsel niteliklerini tespit etmektir. Bu amaçla, açık-yeşil alanlardan meydanlar, parklar, çocuk oyun alanları, spor alanları, okul bahçeleri, resmi kuruluşlar, mezarlıklar, pazaryerleri ile yollar, yaya yolları, refüj ve bulvarlar incelenmiştir. Burdur kentinde kişi başına $8.4 \mathrm{~m}^{2}$ açık-yeşil alan düştüğü ve bu alanın yetersiz olduğu belirlenmiş̧ir. Bu çalışmanın bulguları bütün olarak düşünüldüğünde, Burdur kenti mevcut açık-yeşil alanlarının gelişigüzel bir dağılıma sahip oldukları sonucuna ulaşılmıştır. Ayrıca, kentte yer alan açık-yeşil alanların bitkilerinin estetik ve işlevsel özellikleri açısından kent insanının ihtiyaçlarını karşılayacak nitelikte olmadığı, bitkisel tasarımın yetersiz olduğu ve kullanılan bitki türlerinin mekanın kalitesini artırmada yeterli olmadığı gözlenmiştir. Sonuç olarak, Burdur kentini modern, yaşanabilir ve kaliteli bir mekan haline getirmek için, açık-yeşil alanları nitelik ve nicelik yönünden konunun uzmanları tarafından planlanması ve tasarlanması uygun olacaktır.
\end{abstract}

\begin{abstract}
The aim of this study is to examine the current state of the open-green lands of Burdur city, and to determine their competencies and functional qualities. For this purpose, squares, parks, playgrounds, sport fields, school gardens, public institutions, cemeteries, marketplaces and roads, pedestrian paths, refuges and boulevards of open-green lands were examined. It was determined that there was $8.4 \mathrm{~m}^{2}$ open-green land per capita in Burdur city and this land is inadequate. As considered the findings of the present study as whole, it was found out that the existing open-green lands of Burdur city had a haphazard distribution. In addition, it was observed that the plants of the open-green lands in the city were not enough to meet the needs of the urban people in terms of their aesthetic and functional characteristics, plant design was insufficient and the plant species used were not sufficient to increase the quality of the space. As a result, in order to make the city of Burdur a modern, livable and quality place, it would be suitable to be planned and designed the open-green lands by the related experts in terms of quality and quantity.
\end{abstract}

\section{Giriş}

Günümüzde insanlar artık kentlerde yaşamak istemektedir. Bunun sonucunda oluşan hızlı ve düzensiz kentleşmeyle birlikte aşırı nüfusun intiyacını karşılayabilmek için yapılaşma hızlı bir şekilde artmakta ama açık-yeşil alanların hem niceliği hem de niteliği azalmaktadır. Rostami ve ark. (2013) yaptıkları çalışmalarında belirttikleri üzere, yeşil alanların niteliği kentlerin yaşama, çalışma, yatırım ve turizm alanlarında çekiciliğini artırabilen kent kimliğini tanımlamak için olumlu yönde katkı sağlamaktadır. Böylece, yeşil alanlar kentlerin sürdürülebilirliği ve sağııkı gelişmeleri açısından büyük bir öneme sahiptirler (Akbulut ve Önder 2011).
Doğal, kültürel ve sosyal elemanların birbirleriyle bütün oluşturduğu kentlerde, doğal alanlar korunmayarak, yerlerine yapay, sağlıksız ve kalitesiz çevre oluşturulmaktadır. Bu çevrede yaşayan insanlar; psikolojik, fiziksel ve sosyal intiyaçlarını karşılayıp, rahat edecekleri, mekan arayışı içerisine girmektedirler. Yaşam kalitesini artıran, insanlara rekreaktif etkinlikler sağlayan seçeneklerden biri olan açık-yeşil alanlar önem teşkil etmektedir (Akbulut ve Önder 2011, Menteşe 2019). Bu bağlamda, kentsel açık-yeşil alanlar doğanın kent ortamı içerisindeki bir unsuru olarak görülmektedir (Eroğlu ve ark. 2016).

Açık-yeşil alanlar, şehrin fiziksel ve sosyal yapısının oluşmasını destekleyen, farklı etkinlikler arasında da 
denge kurarak biçimlendiren alanlardır. Açık-yeşil alanların yaşama kalitesini onarma fonksiyonlarından yararlanmak gelecek için büyük önem teşkil eder (Akbulut 2007). Açık-yeşil alanların büyüklük, konum, ulaşılabilirlik, nitelik ve sunu çeşitliliği açısından yeterlilikleri, toplumun bu alanlardan kolayca, çaba sarf etmeden faydalanmaları için son derece önemlidir (Önder ve Polat 2012, Kömür Ardalı 2018). Kent planlama aşamasında yitirilen doğanın, kente ve kent insanına belirlenen normlarda yeniden kazandırılması önem arz etmektedir. Kentteki nüfus artışına paralel olarak açık-yeşil alanlarında hızla planlanıp uygulanmaya konması, kaliteli, modern ve sağlıklı bir kent için büyük önem teşkil etmektedir (Eroğlu ve ark. 2016, Kömür Ardalı 2018). Özellikle, kentsel açık-yeşil alanlar son yıllarda kabul gören sürdürülebilir şehir planlama modellerinde önemli bir unsur olmuştur (Rakhshandehroo ve ark. 2015).

Bugüne kadar Türkiye'de; Isparta (Gül ve Küçük 2001), Artvin (Eminağaoğlu ve Yavuz 2005), Kayseri (Ülger ve Önder 2006), İstanbul-Bayrampaşa (Öztürk Levend ve Önder 2009), Elazığ (Şengün ve Üstündağ 2009), Aksaray (Akbulut ve Önder 2011), Ordu (Atabeyoğlu ve Bulut
2012), Kırklareli (Yücesu ve ark. 2017), Manisa-Turgutlu (Menteşe ve ark. 2018), Ankara-Gölbaşı (Doğan 2019), Bilecek (Menteşe 2019) ve Niğde (Olgun ve Yılmaz 2019) kentlerinin açık-yeşil alanları nitelik ve nicelik açısından değerlendirilmiştir. Burdur kentinin çocuk oyun alanları, mahalle-semt parkları ve spor tesis alanları mekânsal yeterlik ve erişilebilirlik yönünden (Yenice 2012), ilköğretim okulları mekânsal yeterlilik yönünden (Yenice 2013) ve ayrıca Burdur toplu konut ve site alanları açıkyeşil alanları peyzaj tasarım ölçütlerine dayalı olarak (Yücedağ ve ark. 2017) incelenmiştir. Buna karşllık, Burdur kenti açık-yeşil alanlarının nitelik ve niceliği üzerine kapsamlı bir çalışma yürütülmemiştir. Bu çalışmanın amacı, Burdur kenti açık-yeşil alanlarının mevcut durumunu incelemek, yeterlikleri ve işlevsel niteliklerini tespit etmektir.

\section{MATERYAL VE YÖNTEM}

Çalışmanın materyalini Burdur kent merkezinde bulunan mevcut açık-yeşil alanlar oluşturmaktadır. Burdur Belediye'sinde toplam 35 adet mahalle bulunmaktadır (Şekil 1).

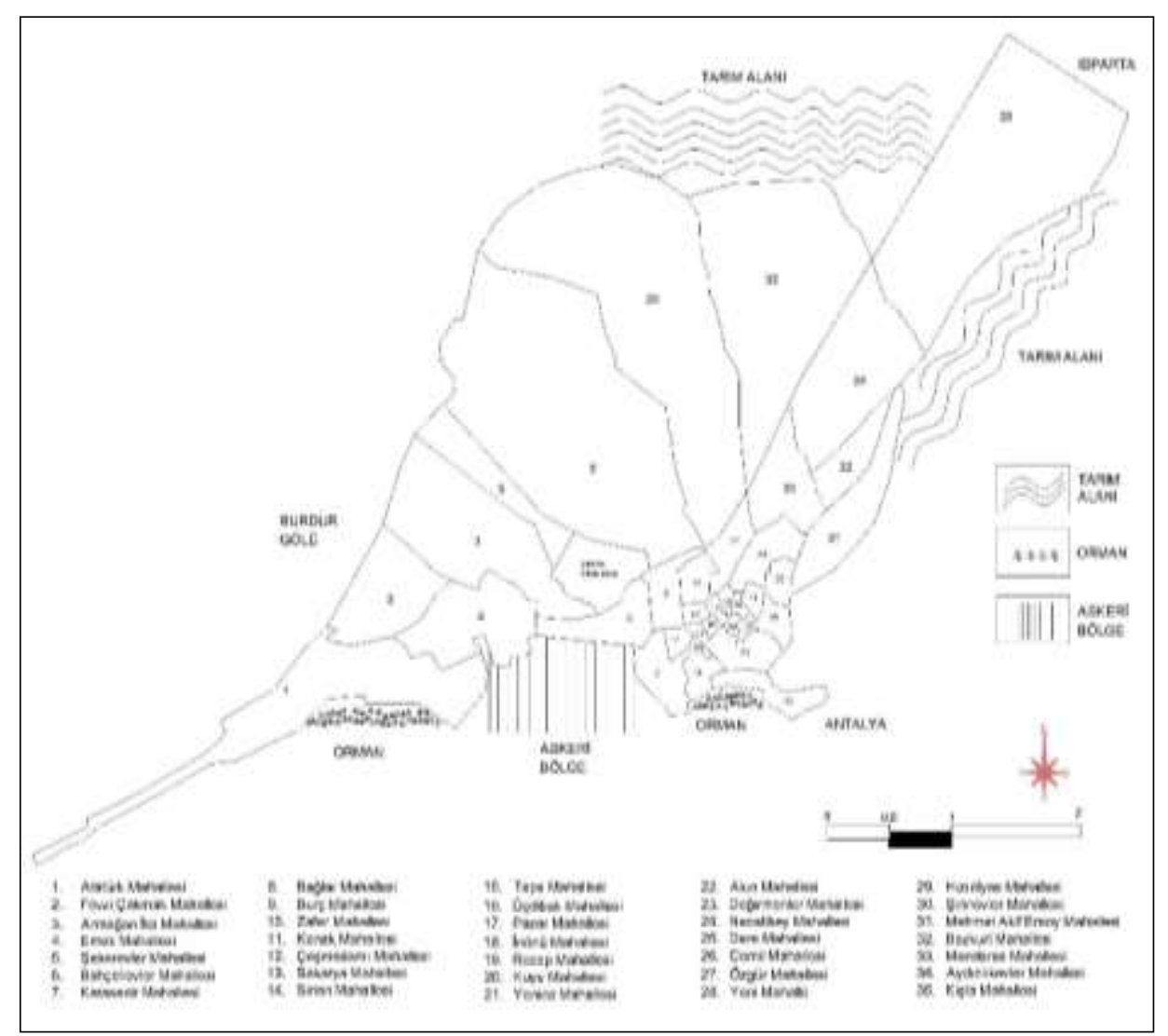

Şekil 1. Çalışma alanındaki mahallelerin konumu 
Burdur ili Güneybatı Anadolu'da Göller Bölgesi'nde bulunur ve $36^{\prime}-53^{\prime \prime}$ ve $37^{\prime}-50^{\prime \prime}$ kuzey enlemleri ile $29^{\prime}-24^{\prime \prime}$ ve 30'-53" doğu boylamları arasında yer alır. Yüzölçümü 6 $883 \mathrm{~km}^{2}$ olan il, güney ve doğuda Antalya, batıda Denizli, güneybatıda Muğla, kuzeyde Afyon, kuzeydoğuda ise Isparta illeri ile çevrelenmiştir. Burdur ilinin merkez ile birlikte toplam 11 ilçesi bulunmaktadır. Bu ilçeler; Kemer, Bucak, Karamanlı, Altınyayla, Ağlasun, Tefenni, Yeşilova, Çeltikçi, Çavdır ve Gölhisar ilçeleridir. Burdur ilinde 30 adet belediye, 13 adet bucak, 182 adet köy bulunmaktadır. Bu köylerin 168 tanesi orman köyü statüsündedir. Orman köylerinin 42 tanesi orman içinde, 126 tanesi de orman bitişiğinde yer almaktadır (Anonim 2019a).

2019 yılı nüfus sayımı sonuçlarına göre, Burdur'un il nüfusu 113 077, kentin nüfusu 90 303'dür (TÜiK 2019). Burdur Belediyesi ilk olarak 1873 yılında kurulmuştur. ilk nazım imar planı 1940 yılında, ikinci detaylı bir imar planı ise 1971 yılında uygulanmaya başlanmıştır. Illave imar planı 1987 ve 2012 yıllarında tamamlanmıştır (Anonim 2019b).

Çalışma alanıyla ilgili çeşitli kurumlar ve araştırmacılar tarafından hazırlanan raporlar, projeler ve faaliyet raporlarından yararlanılmıştır. Çalışmada açık-yeşil alanlar yerinde incelenerek mevcut yapısı güncel fotoğraflarla desteklenmiştir. Çalışma alanının açık-yeşil alanlarının nicelik ve işlevselliği; meydanlar, parklar, çocuk oyun alanları, spor alanları, okul bahçeleri, resmi kuruluşlar, mezarlıklar, pazaryerleri ile yollar, yaya yolları, refüj ve bulvarlar olmak üzere 9 başlık altında incelenmiştir. Öncelikle kentin açık-yeşil alanlarının güncel durumları ortaya konulmuştur. Sonra ise, yerinde yapılan gözlemler ile Burdur Belediyesi İmar ve Şehircilik Müdürlüğü 1/5.000, 1/1.000 ölçekli Nazım İmar Planı, Açıklama Raporları ve Park Bahçe Müdürlüğü'nden elde edinilen bilgilere dayalı kent merkezinde bulunan açıkyeşil alanların mevcut miktarları hesaplanmış, nitelik ve nicelik bakımından yeterliliği irdelenmiştir. Araştırmada son olarak, elde edilen veriler Bayındırlık ve İskan Bakanlığı ile 3194 Sayılı İmar Kanununda belirtilen standartlar dikkate alınarak değerlendirilmiş ve Burdur kenti açık-yeşil alanları ile ilgili önerilerde bulunulmuştur.

\section{BULGULAR ve TARTIŞMA}

\section{Meydanlar}

Toplumun organik parçası olan meydanlar önceden insanların ortak yaşama merkezleri olarak algılanırken (Uzun 1990), günümüzde eski algı işlevini yitirmiş artan nüfusa bağlı trafik yoğunluğunu hafifleten alanlar olarak tanımlanmaktadır (İnceoğlu ve Aytuğ 2009). İmar Planlarında ayrılmış Burdur kenti için Cumhuriyet ve Şeker Meydanları olmak üzere iki meydan mevcuttur. Bu iki meydanın toplam alanı $10538 \mathrm{~m}^{2}$ olup, kişi başına $0.1 \mathrm{~m}^{2}$ alan düşmektedir.

Cumhuriyet Meydanı 1923 yılından beri hizmet vermektedir. Hükümet binası taşınmadan önce belediye çalışanları tarafından daha aktif kullanılan bu meydan şimdi yalnızca tören alanı, festival-bayramlaşma alanı, yürüyüş ve bekleme alanı, konuşma alanı, toplanma alanı gibi işlevlerde kullanılmaktadır. Cumhuriyet meydanının aşağısında cumhuriyet parkı bulunmaktadır. Oturma, dinlenme, bekleme, park, yeşil alan, rekreasyonel mekan, buluşma noktası ya da bazı zamanlarda ticari amaçla (kermes vb.) bile kullanılmaktadır. $1500 \mathrm{~m}^{2}$ sert zemin alanına sahip Cumhuriyet Meydanı'nda $5338 \mathrm{~m}^{2}$ yeşil alan bulunmaktadır. Meydan ve park ana caddeyle bölünmüş olup trafik yoğunluğu yüzünden güvenli olmayıp estetik anlamda da yetersizdir. Mevcut meydan büyüyen gelişen kent ihtiyacını büyüklük ve planlama açısından nitelik ve nicelik anlamda karşılayamamaktadır. Bu meydan da kişi başına düşen oran yeşil alan bakımından yetersiz ve standartların altındadır. Şeker Meydanı 2009 yılından sonra belediye tarafından imar planında meydan olarak gösterilmiştir. Genellikle konser alanı olarak kullanılan alan, 2018 yılında kenti canlandırmak adına belediye tarafından yapılan su gösterileri ile de ziyaret edilmektedir. Şeker Meydanı 3 $700 \mathrm{~m}^{2 \prime}$ lik alana sahip peyzaj donatıları bakımından iyi tasarlanmış bir alandır (Şekil 2). 

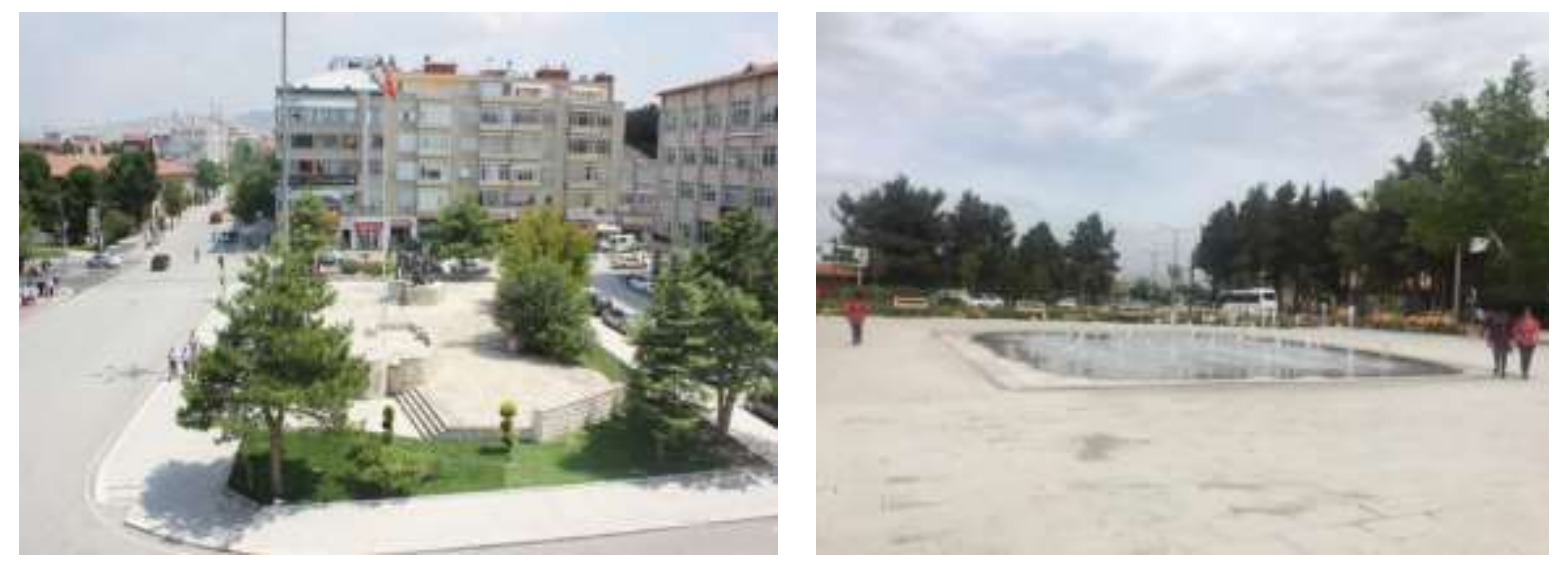

Şekil 2. Cumhuriyet (solda) ve Şeker (sağda) Meydanları

\section{Parklar}

Parklar büyüklüklerine, uzaklık mesafelerine içlerinde bulunan aktivite çeşitliliğine, yetki alanlarına ve hitap ettikleri nüfusa göre sınıflandırılmaktadırlar. Parklar ve rekreasyon alanları; mahalle parkları, semt parkları, kent parkları, milli parklar, bölgesel parklar, ormanlar, koru alanları ve fidanlıklar olarak da farklı gruplandırılabilmektedir (Önen 2015). Burdur Kentinde Kent parkı düzeyinde alan bulunmamaktadır. Burdur da bulunan Alyazmalım ve Mehmet Akif Ersoy Kent Ormanları pasif alan olarak değerlendirilmiştir. Burdur Kenti mahallelerinde toplam 131 park bulunmaktadır (Şekil 3). Tüm parklarda yeşil alanlara yer verilmiştir. Burdur Kentinde kişi başına düşen park miktarı sert zeminlerde dahil $3.0 \mathrm{~m}^{2} /$ kişi olarak bulunmuştur. Fakat sadece parklarda bulunan yeşil alanı göz önünde bulunduracak olursak, parklarda kişi başına 1,6 $\mathrm{m}^{2}$ yeşil alan düşmektedir.

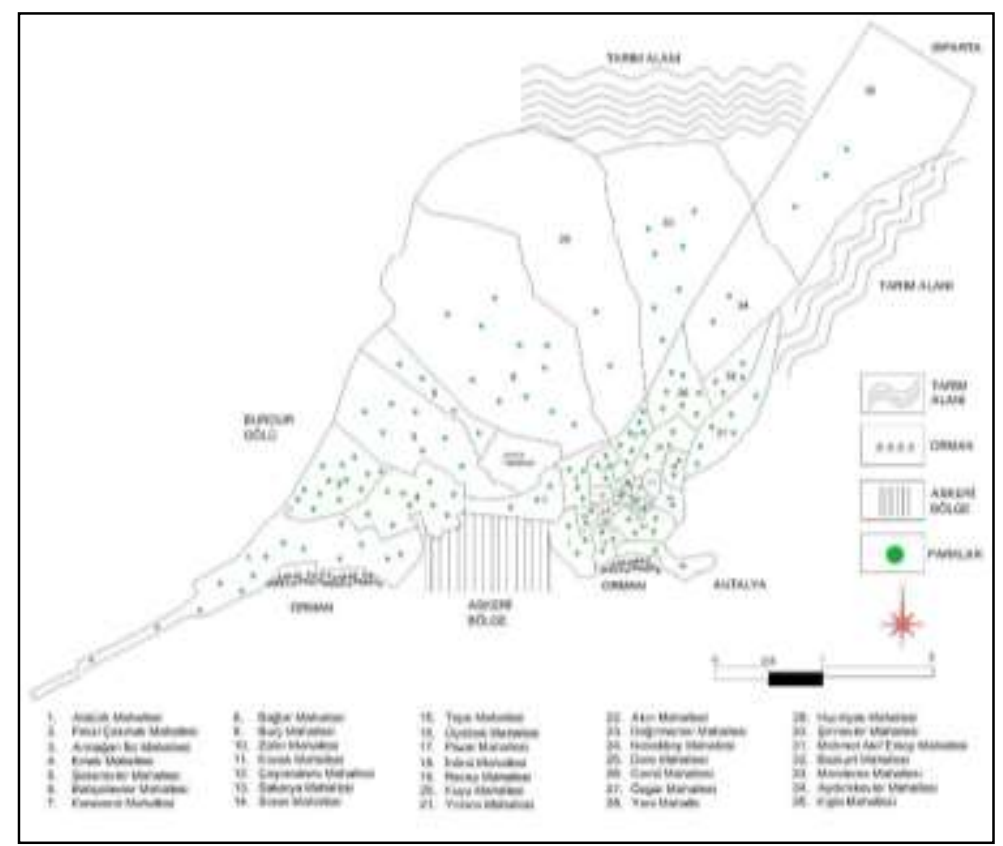

Şekil 3. Burdur kenti mahallerinde bulunan parklar

\section{Çocuk Oyun Alanları}

Burdur kentinde 90 çocuk oyun alanı bulunmaktadır (Şekil

4). Kentte bulunan mahallelerden Çeşmedamı, Sakarya,
Sinan, Üçdibek, Recep ve İnönü mahalleleri hariç, diğer 29 mahallede nüfus/çocuk yoğunluğuna bağlı olarak birden fazla çocuk oyun alanına yer verilmiştir. Çocuk oyun alanları nicelik bakımından fazla gözükse de, nitelik olarak 
kendini tekrarlayan, yaratıcılıktan ve tasarımdan yoksun tek tip mekanlar olduğu saptanmıştır. Halbuki, çocuk oyun alanları, çocukların fiziksel aktivitelerini ve enerjilerini harcadığı kadar, hayal dünyalarını geliştirecek ve becerilerini artıracak alanlar olmalıdır. Çocuk oyun alanlarının planlama ve tasarım sürecine gereken önemin verilmediği görülmektedir. Kentte bulunan çocuk parkları her ne kadar çocuklar için farklı aktivite ve oyunlar içermese de akşam saatlerinde, hafta sonlarında çocukların yoğun kullanımına sahne olmaktadır.

Burdur kenti 0-17 yaş arası çocuk nüfusu toplam 56447 (TUik 2019), toplam çocuk oyun grupları da dahil park alanı $41988 \mathrm{~m}^{2 \prime}$ dir. Çocuk nüfusu başına düşen çocuk oyun alanı miktarı $0.7 \mathrm{~m}^{2} /$ kişi'dir. Bayındırlık ve İskan Bakanlığının standardına göre ise bu değer $1,5 \mathrm{~m}^{2} /$ kişi olmalıdır.

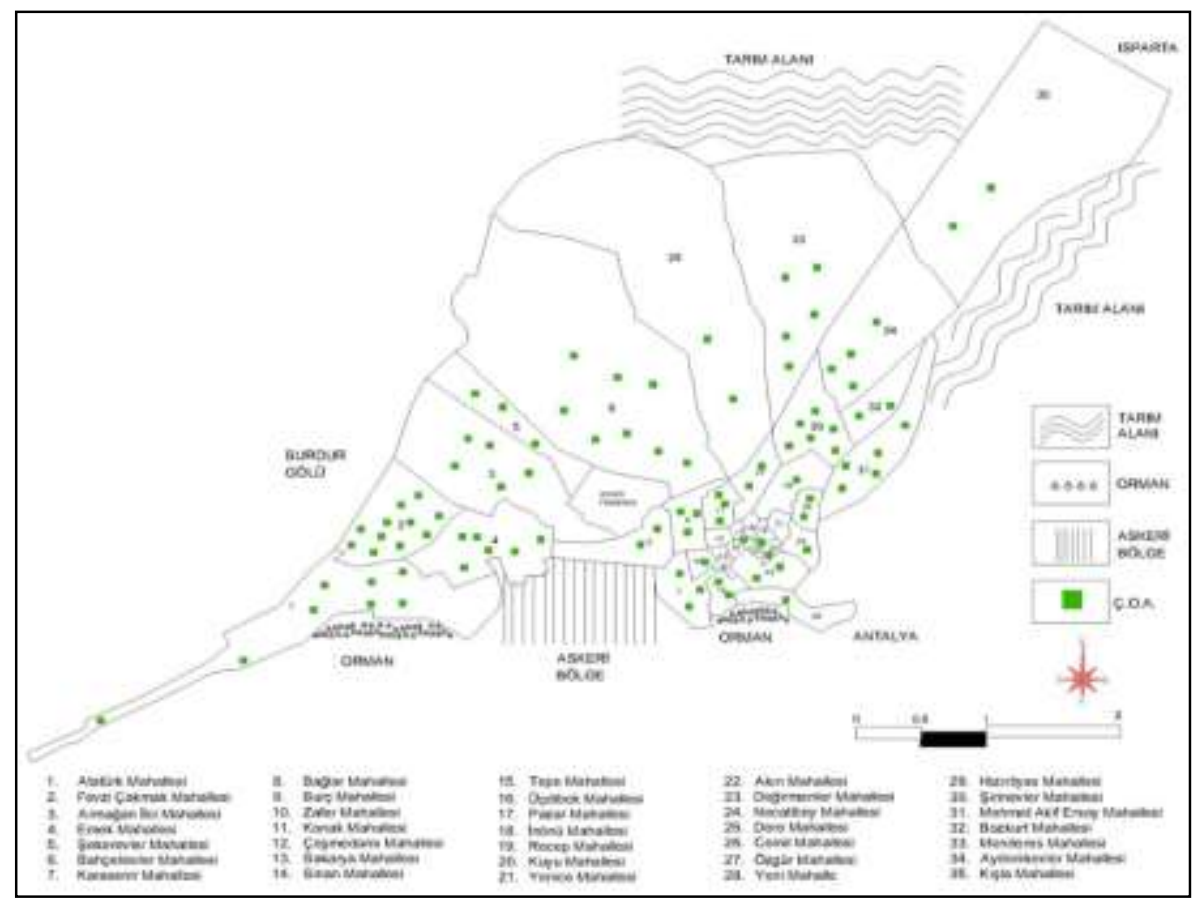

Şekil 4. Burdur kenti mahallerinde bulunan çocuk oyun alanları

\section{Spor Alanları}

Burdur kenti spor alanları son birkaç yılda yapılan çocuk oyun alanları içinde düşünülmüş mini futbol ve basketbol alanları içine girmemekle beraber, mülkiyeti Gençlik ve Spor İl Müdürlüğü bünyesindeki kompleks alanlardır. Kent spor alanlarının toplam alanı $84146 \mathrm{~m}^{2}$, kişi başına düşen spor alanı $0.9 \mathrm{~m}^{2}$ olup (Çizelge 1), bu alan çok yetersizdir. Benzer şekilde, Yenice (2012) mahalle üniteleri düzeyindeki yeşil alan kullanımlarından olan spor tesis alanlarının mekânsal yeterlilik ve erişebilirlik olanakları açısından Burdur kentinde dengesiz dağılım gösterdiğini ve mekânsal standartlar açısından yetersiz olduğunu ifade etmiştir.

Çizelge 1. Burdur kentinde bulunan spor alanları (Anonim 2019c)

\begin{tabular}{ll}
\hline Spor Tesisinin Türü & Alanı $\left(\mathrm{m}^{2}\right)$ \\
\hline Burdur Gazi Atatürk Stadı, Burdur Gençlik Merkezi, Yüzme Havuzu & 33780 \\
Burdur Tenis Kortları & 3687 \\
Kışla Semt Sahası & 21446 \\
Çendik Su Sporları Eğitim Merkezi & 5233 \\
Çendik Trap Atış Alanı & 20000 \\
\hline Toplam & 84146 \\
\hline
\end{tabular}




\section{Okul Bahçeleri}

Nüfusun artışı sonucunda ortaya çıkan açık-yeşil alanların azalmasına çözüm olarak, kent mekânlarının çok yönlü kullanılması gerekmekte ve bu amaçla okul bahçelerine de ek işlevler yüklenmektedir (Tepe 2018). Burdur kentinde 5 anaokul, 18 ilköğretim, 18 ortaöğretim, 14 genel lise ve 10 özel eğitim kurumu bulunmaktadır. Toplam öğrenci sayısı 13927 ve okul bahçelerinin toplam alanı $71650 \mathrm{~m}^{2 \prime}$ dir (Anonim 2019d). Öğrenci başına açık alan olarak okul bahçelerinde $5.0 \mathrm{~m}^{2}$ mekan düşmektedir.

Sadece kendi binası olan 10 ilköğretim dikkate alındığında, Burdur kentinde toplam okul bahçesi alanı 22 $110 \mathrm{~m}^{2}$ ve öğrenci başına $6.5 \mathrm{~m}^{2}$ alan düşmektedir. Bu bağlamda, Yenice (2013) ideal alan büyüklüğü ölçütlerinin altında yer alan Burdur kenti ilköğretim okullarının alan büyüklüklerinin arttırılması veya daha etkin kullanımlarına dönük mekânsal düzenlemelere gidilmesinin gerektiğini vurgulamıştır. Bununla birlikte aynı araştırmacı ilköğretim okullarının kentsel mekânda dengeli dağııımının sağlanarak kent içi yeşil koridorlar ile bütünleştirilmesini ile okul çağı çocuklarının yaya-bisiklet ulaşımı ile erişebilecekleri mekânsal düzenlemelerin sağlanması gerektiğini belirtmiştir.

\section{Resmi Kuruluşlar}

Burdur kenti resmi kuruluşları pasif yeşil alanlar olarak önem taşımakta ve kentin yeşil alan intiyacını karşılamaktadırlar. Resmi kuruluşların toplam alanı 98 $620 \mathrm{~m}^{2}$, kişi başına düşen spor alanı $1.1 \mathrm{~m}^{2}$ olup, bu alan çok yetersizdir.

\section{Yollar, Yaya Yolları, Refüjler ve Bulvarlar}

Yollar yeşil alanları birbirine bağlayarak ulaşım ve sirkülasyon işlevinin yanında, kentte açık alan oluşturarak binalara ışık, hava sağlarken; aynı zamanda yeraltı ve yerüstü tesisatlarına da zemin hazırlar. Refüj ve bulvarlar kent trafiğine katkı ve kentlilere az zamanlı rekreasyon imkanı sunar. Burdur kentinde Armağan İlci, Ali Kemal Erdem ve Mustafa Eşref bulvarları olmak üzere toplam 3 bulvar bulunmaktadır. Kentte bulunan yol, yaya yolu, refüj ve bulvarların toplam alanı $79292 \mathrm{~m}^{2}$, kişi başına düşen miktar ise $0.9 \mathrm{~m}^{21}$ dir.

\section{Mezarlıklar}

Burdur kentinde Şirinevler (Şehir) (123 $\left.174 \mathrm{~m}^{2}\right)$, Sultandere $\left(60227 \mathrm{~m}^{2}\right)$ ve Kışla $\left(17500 \mathrm{~m}^{2}\right)$ mezarlıkları olmak üzere toplam 3 mezarlık mevcuttur. Bunlardan Şirinevler Mezarlığı içerisinde Şehitler Mezarlığı da yer almaktadır. Şirinevler mezarlığının kapasitesi dolmaya başladığı için, 2012 yılında Sultandere Mezarlığı faaliyete geçmiştir. Burdur kent merkezinde bulunan mezarlıkların bakımı Belediyenin kontrolü altındadır. Kentte toplam $200901 \mathrm{~m}^{2}$ mezarlık alanı bulunmaktadır ve kişi başına 2 $\mathrm{m}^{2}$ mezarlık alanı düşmektedir.

\section{Pazar Yerleri}

Burdur kentinde pazar yeri olarak ayrılmış mevcutta iki alan bulunmaktadır. İlki uzay çatı olarak bilinen $17605 \mathrm{~m}^{2}$ olan pazar yeri, ikincisi ise Depremevleri'nde bulunan 3 $280 \mathrm{~m}^{2}$ olan Depremevleri Pazar yeridir. Uzay çatı Salı günleri hariç diğer günler otopark veya fuar alanı olarak kullanılırken, Depremevleri Pazar yeri sadece Pazar günleri açık iken, diğer günler kapalıdır. Kişi başına düşen pazar yeri $0,2 \mathrm{~m}^{2 \prime}$ dir.

\section{SONUÇLAR}

Bu çalışmadan elde edilen bulgular dikkate alındığında, Burdur kentinde parklar (kent ormanları hariç), çocuk bahçeleri ve oyun alanları, refüj ve yollar, ağaçlandırma bölgeleri ve meydanlar dahil toplam aktif yeşil alan miktarı $755296 \mathrm{~m}^{2}$, kişi başına $8.4 \mathrm{~m}^{2}$ açık-yeşil alan düşmektedir. Bu sonuç, Burdur kentinin aktif yeşil alanlar bakımından yetersiz olduğunu göstermektedir. Bu değere pasif yeşil alanların da eklenmesi durumunda, kişi başına düşen açık-yeşil alan miktarı 3194 Sayılı İmar Kanunu'nda belirtilen standardın $\left(10 \mathrm{~m}^{2}\right)$ üzerine çıkmaktadır.

Kentte bulunan iki meydan kent halkının toplu etkinlik ve eylemlerini karşılayabilecek nitelikte değil, küçük ve plansızdır. ilgili kişi ya da kurumlar tarafından yeni meydan alanı önerilmeli ve halkın rekreasyon çeşitliliği bu alanlarda artırımalıdır.

Burdur kenti parklarının çoğunun küçük ve dinlenme, spor, oyun gibi aktivitelerin bir arada yer alması nedeniyle kendilerinden beklenen işlevleri yerine 
getirememektedirler. Bu düşük peyzaj standardına sahip parkların yenilenerek estetik ve işlevsel değerler kazandırılması gerekmektedir.

Çocuk oyun alanları her mahallede bulunmasına rağmen, hem nicelik hem de nitelik bakımından yetersizdir. Kent içinde yer alan çocuk oyun alanları çoğunlukla parkların bir kenarında çözümlenmiştir. Ayrıca, genellikle birbirini tekrar eden oyun gruplarını içermektedirler. Kentte çocuk oyun alanları sayısı ve büyüklükleri artırılmalı, mahalle içerisinde dengeli dağılımları sağlanmalı, oyun grubu çeşitliliği artırımalı ve standartlara uygun olarak tesis edilmelidirler.

Genel anlamda Burdur kenti mevcut açık-yeşil alanlarının gelişigüzel bir dağılıma sahip oldukları ve bir bütünlük arz etmedikleri sonucuna ulaşılmıştır. Bu nedenle, açık-yeşil alanların, kent içerisinde dengeli dağılımının sağlanması, konum, büyüklük ve ulaşılabilirlik gibi konularda yeterliliğinin ve kent halkına uygun kullanım koşullarının oluşturulması gerekmektedir. Ayrıca, kentte yer alan açıkyeşil alanların bitkisel materyallerinin estetik ve işlevsel özellikleri açısından kent insanının ihtiyaçlarını karşılayacak nitelikte olmadığı, bitkisel tasarımın yetersiz olduğu ve kullanılan bitki türlerinin mekanın kalitesini artırmada yeterli olmadığı gözlenmiştir. Sonuç olarak, Burdur kentini modern, yaşanabilir ve kaliteli bir mekan haline getirmek için, açık-yeşil alanları nitelik ve nicelik yönünden konunun uzmanları tarafından planlanması ve tasarlanması uygun olacaktır. Ayrıca, açık-yeşil alanların tesisi ve korunması konusunda yerel yönetimi yönlendirme amacıyla Burdur kent insanı bilinçlendirilmelidir.

\section{TEŞEKKÜR}

$\mathrm{Bu}$ çalışma, Açık-Yeşil Alanların Nitelik ve Nicelik Yönünden İncelenmesi: Burdur Kent Merkezi Örneği" başlıklı yüksek lisans tezi verileri kullanılarak hazırlanmıştır. Yüksek lisans tezine katkılarından dolayı Prof. Dr. Mehmet TOPAY'a teşekkür ederiz.

\section{KAYNAKLAR}

Akbulut ÇD (2007) Aksaray kenti açık-yeşil alanların nitelik ve nicelik yönünden değerlendirilmesi. Selçuk Üniversitesi Fen Bilimleri Enstitüsü Yüksek Lisans Tezi, Konya, $210 \mathrm{~s}$.

Akbulut ÇD, Önder S (2011) Kentsel açık-yeşil alanlarda kullanılan bitki materyalinin değerlendirilmesi; Aksaray kenti örneği. Selçuk Tarım ve Gıda Bilimler Dergisi, 25 (2): 93-100.

Anonim (2019a) Çevre durum raporu. Burdur Belediyesi İmar Müdürlüğü, Burdur.

Anonim (2019b) Resmi kayıtlar. Burdur Belediyesi, Burdur.

Anonim (2019c) 2019 yılı spor alanları raporu. Burdur Belediyesi Gençlik Spor ìl Müdürlüğü, Burdur.

Anonim (2019d) 2019 yılı okul-öğrenci sayıları raporu. Burdur î Milli Eğitim Müdürlüğü, Burdur.

Atabeyoğlu Ö, bulut $Y$ (2012) Ordu kenti mevcut yeşil alanlarının değerlendirilmesi. Akademik Ziraat Dergisi, 1 (2): 67-76.

Inceoğlu M, Aytuğ A (2009) Kentsel mekanda kalite kavramı. MEGARON, 4 (3): 131-146.

Doğan M (2019) Ankara ilii Gölbaşı İlçesi'nin açık yeşil alan yeterliliği üzerine bir araştırma. Süleyman Demirel Üniversitesi Fen Bilimleri Enstitüsü Yüksek Lisans Tezi, Isparta, $84 \mathrm{~s}$.

Eminağaoğlu Z, Yavuz A (2005) Artvin kent dokusunda yeşil alan incelemesi. Kafkas Üniversitesi Artvin Orman Fakültesi Dergisi, 6 (1-2): 191-202.

Eroğlu E, Acar C, Aktaş E (2016) Kentsel açık ve yeşil alanlara yeni bir soluk; Ordu şehir ormanı ve botanik parkı peyzaj proje çalışması. ARTIUM, 4 (2): 30-42.

Gül A, Küçük V (2001) Kentsel açık-yeşil alanlar ve Isparta kenti örneğinde irdelenmesi. Süleyman Demirel Üniversitesi Orman Fakültesi Dergisi, Seri A, Sayı 2, 27-48.

Kömür Ardalı Z (2018) Beylikdüzü ilçesi açık yeşil alan sisteminin mevcut durumunun değerlendirilmesi. Tekirdağ Namık Kemal Üniversitesi Fen Bilimleri Enstitüsü Yüksek Lisans Tezi, Tekirdağ, $151 \mathrm{~s}$.

Menteşe S, Böbrek O, Çakmak F (2018) Turgutlu'da (Manisa) açık-yeşil alanların değerlendirilmesi. TÜCAUM 30. Yıl Uluslararası Coğrafya Sempozyumu, 3-6 Ekim 2018, Ankara.

Menteşe S (2019) Bilecik şehir merkezinde kentsel açık-yeşil alanların değerlendirilmesi. Uluslararası Sosyal ve Beşeri Bilimler Araştırma Dergisi 6 (33): 373-379.

Olgun R, Yılmaz T (2019) Kentsel yeşil alan varlığının Niğde kenti örneğinde değerlendirilmesi. Mediterranean Agricultural Sciences, 32 (1): 11-20.

Önder S, Polat AT (2012) Kentsel açık-yeşil alanların kent yaşamındaki yeri ve önemi. Kentsel Peyzaj Alanlarının Oluşumu ve Bakım Esasları Semineri, 19 Mayıs 2012, Konya.

Öztürk Levend T, Önder S (2009) İstanbul ili Bayrampaşa İlçesi açıkyeşil alanlarının değerlendirilmesi. Selçuk Tarım ve Gıda Bilimler Dergisi, 23 (48): 1-12.

Rakhshandehroo M, Mohdyusof MJ, Tahırholder OM, Yunos MYM (2015) The socialbenefits of urban open green spaces: a literature review. Management Research and Practice 7 (4): 60-71. 
Rostami R, Lamit H, Khoshnava SM, Rostami R (2013) Urban green spaces and city sustainability. Asian Journal of Microbiology, Biotechnology and Environmental Sciences 15 (2): 441-446.

Şengün MT, Üstündağ Ö (2009) Elazığ şehir merkezinde yeşil alan kullanımlarının dağılımına coğrafi bir bakış. Doğu Coğrafya Dergisi, 14 (22): 45-68.

Tepe AC (2018) Açık ve Yeşil Alanların Kentsel Yaşam Kalitesine Etkisinin Belirlenmesi: Sancaktepe Örneği, Doktora Tezi, Düzce Üniversitesi Fen Bilimleri Enstitüsü, Düzce.

TÜiK (2019) http:// http://www.tuik.gov.tr (Erişim tarihi: 08.05.2019)

Uzun G (1990) Kentsel rekreasyon alan planlaması. Çukurova Üniversitesi Ziraat Fakültesi Ders Kitabı No:48, Adana.
Ülger FN, Önder S (2006) Kayseri kenti açık- yeşil alanlarının nitelik ve nicelik açısından irdelenmesi. Selçuk Üniversitesi Ziraat Fakültesi Dergisi, 20 (38): 108-118.

Yenice MS (2012) Kentsel yeşil alanlar için mekânsal yeterlilik ve erişebilirlik analizi; Burdur örneği, Türkiye. SDÜ Orman Fakültesi Dergisi 13: 41-47.

Yenice MS (2013) İlköğretim okulları için mekânsal yeterlilik analizi; Burdur örneği. Hacettepe Üniversitesi Eğitim Fakültesi Dergisi, 28 (3): 430-439.

Yücedağ C, Kaya LG, Ulu A (2017) Burdur kenti toplu konut ve site alanlarının peyzaj tasarım yeterliliğinin incelenmesi. Mehmet Akif Ersoy Üniversitesi Fen Bilimleri Enstitüsü Dergisi, 8 (2): 114-122.

Yücesu Ö, Korkut A, Kiper T (2017) Kırklareli kent merkezinin açık ve yeşil alanların analizi ve bir sistem önerisi. ARTIUM, 5 (2): 22-37. 